\title{
Environmental Infrasound and Its Impact on Public Health in the Kashmir Region
}

\author{
Raghavan Gopalaswami ${ }^{*}$, Shakil Ahmad Romshoo², Rakesh Chandra², \\ Thennaarassan Natarajan ${ }^{3}$
}

\begin{abstract}
${ }^{1}$ Retired Advanced Systems and Technology Analyst, Formerly with DPSU, Government of India, Hyderabad, India
${ }^{2}$ Department of Earth Sciences, University of Kashmir, Srinagar, Jammu \& Kashmir State, India

${ }^{3}$ Geologist, Junior Research Fellow, Department of Earth Sciences, University of Kashmir, Srinagar, Jammu \& Kashmir State, India

Email: ^gopalaswami@gmail.com
\end{abstract}

How to cite this paper: Gopalaswami, R., Romshoo, S.A., Chandra, R. and Natarajan, T. (2019) Environmental Infrasound and Its Impact on Public Health in the Kashmir Region. Open Journal of Earthquake Research, 8, 165-190.

https://doi.org/10.4236/ojer.2019.83010

Received: April 22, 2019

Accepted: June 3, 2019

Published: June 6, 2019

Copyright $\odot 2019$ by author(s) and Scientific Research Publishing Inc. This work is licensed under the Creative Commons Attribution International License (CC BY 4.0).

http://creativecommons.org/licenses/by/4.0/

\begin{abstract}
In earlier published studies it was shown that an anomalous degree of human physiological ailments and a psychology of sustained anger and violence exist in highly populated countries located on boundaries of colliding Tectonic Plates in three continents at Latitude $34^{\circ}$ north. The Valley of Kashmir in Northern India is also located exactly on this latitude, hence chosen for detailed experimental verification of this phenomenon. This region also suffers from chronic public health hazards. Infrasound is very low frequency acoustic wave with frequencies ranging from $0.01 \mathrm{~Hz}$ to $20 \mathrm{~Hz}$. It emanates from earthquakes, geological Faults, colliding tectonic plates and atmospheric wind turbulence. Hearing protections like ear muffs and ear plugs offer little protection. One single earthquake can cause multiple infrasound sources in a region. It is shown how regional geomorphology in the Kashmir Valley enhances and sustains this phenomenon. Both the percentage of population with hearing disabilities; and casualties due to social violence increase or decrease in proportion to frequency of earthquakes. Infrasound is shown to be the causal linkage. Public health hazards due to environmental infrasound closely resemble public health hazards actually being suffered by the population in Kashmir as established by formal and extensive medical investigations. Hence a Field Study was carried out to locate and record infrasound emissions in ten locations near $34^{\circ} \mathrm{N}$ latitude in Kashmir Valley. An analytical technique was developed to integrate infrasound spectrum in specific locations with public health hazards. It was discovered that infrasound recorded in South Kashmir around $34^{\circ} \mathrm{N}$ latitude at the locations of highest amplitude lies in proximity of Active Faults from earthquake ruptures; and in proximity to a large field of past earthquakes that took place in 2006-2012. A comprehensive public health security system needs to be set up very urgently. Tech-
\end{abstract}


nological measures are identified and appropriate technologies suggested cordoning off and mitigating this natural environmental hazard in the Kashmir Valley.

\section{Keywords}

Environmental Infrasound, Public Health Hazards, Social Violence, Regional Field Study, Active and Passive Sound Cancellation

\section{Introduction}

Infrasound is acoustic energy with frequencies up to $20 \mathrm{Hertz}(\mathrm{Hz})$, having wavelengths of $17 \mathrm{~m}$ or more up to several kilometers. Some definitions give the upper limit of $16 \mathrm{~Hz}$; others restrict infrasound to delivery by air transmission. Infrasound is seldom generated at high sound pressure levels (SPL) usually measured in decibels $[\mathrm{dB}]$ beyond $150 \mathrm{~dB}$ without accompanying audible sound. Environmental infrasound is ubiquitous. It emanates from the earth, oceans and atmosphere. On solid earth, infrasound is emitted during earthquakes, tectonic plate movements, earth ruptures, in mountain valleys, during volcanic activity, and from coal mines. So also infrasound emanates from atmospheric wind turbulence, waves and tsunamis from oceans. Man-made infrasound emanates from transportation and industrial systems. Hearing protection, e.g. ear muffs and ear plugs, offers little protection against infrasound exposure. Hundreds of medical investigations worldwide bring out that exposure to infrasound at specific frequencies and amplitudes damage human metabolism and lead to a variety of serious psychological ailments; and (at higher infrasound amplitudes) physiological ailments as well like hearing disabilities.

Background to this Study: The Valley of Kashmir is a region of the northwestern Indian subcontinent. It is bounded by the Uygur Autonomous Region of Xinjiang to the northeast and the Tibet Autonomous Region to the east (both parts of China), by the Indian states of Himachal Pradesh and Punjab to the south, by Pakistan to the west, and by Afghanistan to the northwest. The region has a total area of some 85,800 square miles $(222,200$ square $\mathrm{km})$. The modern state of Jammu and Kashmir extends [1] from $32 \mathrm{deg} 78^{\prime}$ to $36 \mathrm{deg} 58^{\prime} \mathrm{N}$ and from 73 deg $27^{\prime}$ to 80 deg 72 'E. Kashmir, if literally translated, means land desiccated from water: "ka" (the water) and "shimeera" (to desiccate). Tradition says that Kashmir was originally a lake that was drained by a great sage of ancient India, Kashyapa.

The Kashmir region is unique in that it has witnessed a sustained period of social turmoil and violence since historical times. Sadly the region has never known what true peace is. Kashmir lost its sovereignty to Mughal emperor Akbar on October 6, 1586. The never-ending fight for autonomy continues to his day. Kashmir was a tourist's paradise during the 1970s and early 1980s. However 
tourism in Kashmir declined during the late 1980s and 1990s, and thousands of innocent Kashmiri lives are said to have been lost due to due to violence.

Over the last 18 months, studies [2] [3] revealed that the centuries of unresolved ethnic conflict existed not only in the Kashmir region at 34 degrees north latitude, but indeed over 10,000 kilometers of the Asian continent around this very same latitude along the boundaries of colliding tectonic plates. The one common geophysical feature was that the entire region along this latitude was highly seismic. Earlier published research on "Hotspots" of high seismicity in West, Central and South Asia particularly in the region within the boundary of colliding tectonic plates at $34^{\circ} \mathrm{N}$ latitude are also shown to be regions of ethnic conflict.

It was then seen that as the as the frequency of earthquakes increased and decreased over a period of time, so too did casualties due to action of security forces. Here then was a clue. All that remained was to discover the causal relationship and mechanism between earthquakes and social violence. In October 2017, a first published paper [4] proposed a hypothesis that among the many potential sociological, biological and geopolitical causes of anti-social and violent behavior in human populations, environmental emissions of infrasound is identified as a potential harmful factor. The paper presented comprehensive findings of scientific studies on infrasound science and technology; infrasound toxicology research; sociology; geology and geophysics and analysed for correlations.

Motivation for This Study: The need for experimental verification of this hypothesis at least in such "Hotspot" regions was thus found to be paramount. In 2018, it was seen that comprehensive public health studies in Kashmir brought out by an international team of doctors had brought out that a sizable percentage of the regional population remain in a constant state of irritation, annoyance and anger; and suffer many other psychosomatic ailments that this Study ascribes as corresponding to exposure to infrasound. This public hazard is shown in Table 1.

Table 1. Annoyance, oppressiveness and pain, public health effect of infrasound amplitude thresholds (dB).

\begin{tabular}{cccc}
\hline Frequency $(\mathrm{Hz})$ & Annoyance & Oppressiveness & Pain \\
\hline 1 & 100 & 120 & 135 (max) \\
5 & 70 & 115 & 130 \\
10 & 60 & 110 & 115 \\
20 & 50 & 95 & 105 \\
\hline
\end{tabular}

Source: Data for Table 1 extracted from Figure 1. "Threshold of detection (Green), Threshold of Annoyance-Oppressive (Orange) and Threshold of Pain-Physiological effects" (Red) in Bob Thorne "Propagation thresholds and measurement of infrasound to establish separation distances from wind farm turbines to residences" https://www.acoustics.asn.au/conference_proceedings/INTERNOISE2014/papers/p599.pdf.

Thus by 2018 a new natural hazard inimical to life on planet earth was identified. The time had arrived to locally pinpoint infrasound hotspots by scientific measurements. 
This paper presents the results of such detailed field studies by geologists equipped with modern precision instrumentation to detect and continuously record sustained emissions of infrasound in the Kashmir Valley. Thereafter new technologies can be developed to actively, and passively, mitigate/cancel these dangerous geophysical energies.

\section{Objective}

The objective of this paper describes the presence and characteristics of sustained emissions of environmental infrasound in the Kashmir Valley as recorded by exploratory field measurements, determine likely source(s), analyse the potential health hazards to population living in these locations, compare these hazards with earlier public health studies, and suggest measures to mitigate/eliminate this insidious natural hazard.

\section{Methods}

The following methodology was adopted to correlate cause and affect i.e. environmental infrasound and public health in Kashmir.

1) Obtain the characteristics of infrasound emitted during earthquakes and other seismic events worldwide.

2) Study the geology of Kashmir Valley for its potential to generate infrasound.

3) Summarize the human health hazards from exposure to infrasound.

4) Study the "Muntazar Kashmir Mental Health Report-2015" and use its findings as the Baseline Reference Document for actual public health in Kashmir.

5) Combine these themes into a single format that correlates a specific ailment with a specific infrasound frequency and amplitude.

6) Carry out a Field Survey \& Exploration for Infrasound Sources in the Kashmir Valley.

7) Determine the health hazard in each location as ascribed to infrasound and compare them with the findings of Muntazar Health report.

8) Summarize and present measures to ameliorate/eliminate infrasound emissions at their source.

9) Present recommendations for action by Public Authorities.

\section{Environmental Infrasound}

\section{A Comprehensive Survey}

During the five month period of field Studies (November 2018 to March 2019) no earthquakes were recorded in Kashmir Valley. Infrasound emissions from earthquakes have been recorded since 1970s. A few typical events are described in Table 2.

Other Potential Sources of Environmental Infrasound Natural and manmade sources that have the potential to generate infrasound in the Kashmir region are shown in Table 3. The frequency domain where infrasound emanates from each source is indicated. The amplitude of infrasound could vary from low values around 2 to $3 \mathrm{~dB}$ to as high as over $150 \mathrm{~dB}$. 
Table 2. Typical characteristics of infrasound emissions from earthquakes.

\begin{tabular}{|c|c|c|c|}
\hline \multirow[b]{2}{*}{ Region } & \multirow[b]{2}{*}{ Date } & \multicolumn{2}{|c|}{ Typical Seismic Event } \\
\hline & & $\begin{array}{l}\text { Earthquake } \\
\text { Strength }\left(\mathrm{M}_{\mathrm{W}}\right)\end{array}$ & $\begin{array}{l}\text { Predominant } \\
\text { Infrasound Frequency } \\
\text { Range }(\mathrm{Hz})\end{array}$ \\
\hline China & 28 June 2002 & 7.3 & $0.1-3.0 \mathrm{~Hz}$ \\
\hline $\begin{array}{l}\text { Czech Republic } \\
\text { (Westernmost region) (2008) }\end{array}$ & 2008 & $\begin{array}{l}\text { Relatively weak } \\
\text { earthquake }\end{array}$ & $\sim 1-12 \mathrm{~Hz}$ \\
\hline Israel & \multicolumn{2}{|c|}{$\begin{array}{l}\text { Based on analysis of some } 4500 \\
\text { micro-tremor measurements at } \\
\text { various locations within } 15 \text { cities of Israel }\end{array}$} & $\begin{array}{l}2.5 \text { to } 3.5 \mathrm{~Hz} \\
\text { (simulated) }\end{array}$ \\
\hline Italy & $2012-2016$ & $5.9-6.5$ & $0.75 \mathrm{~Hz}$ to $14.0 \mathrm{~Hz}$ \\
\hline $\begin{array}{l}\text { Peru (2001) } \\
\text { Coast of South-Central Peru }\end{array}$ & 23 June 2001 & 8.4 & $0.05-1 \mathrm{~Hz}$ \\
\hline $\begin{array}{l}\text { Sumatra \& Tsunami } \\
\text { that followed }\end{array}$ & $\begin{array}{l}\text { Dec. } 26,2004 \text { to Apr. } \\
\text { 10, } 2005\end{array}$ & M 9.0 to M 6.5 & $0.02-0.15 \mathrm{~Hz}$ \\
\hline USA & $\begin{array}{l}\text { Analysis from } 31 \\
\text { earthquakes in USA } \\
1983-2003\end{array}$ & M 4.4 to M 7.5 & $0.13 \mathrm{~Hz}$ to $2.46 \mathrm{~Hz}$ \\
\hline
\end{tabular}

Table 3. Potential sources of environmental infrasound.

\begin{tabular}{|c|c|c|}
\hline Sl. No & Potential Sources of Environmental Infrasound & $\begin{array}{l}\text { Likely Frequency } \\
\text { (from multiple literature sources) } \\
(\mathrm{Hz})\end{array}$ \\
\hline 1 & $\begin{array}{l}\text { Tectonic plate movements at Latitude } 34^{\circ} \mathrm{N} \text { in North } \\
\text { Western Himalaya Mountains and teleseismic activity } \\
\text { from global seismic events and due to local/regional } \\
\text { seismic activity }\end{array}$ & $\begin{array}{l}\text { Not known } \\
\text { TO BE INVESTIGATED }\end{array}$ \\
\hline 2 & Mountain Air Turbulence & $0.01-1.0$ \\
\hline 3 & $\begin{array}{l}\text { Earthquakes > Mag. } 2 \text { within and in the neighborhood } \\
\text { of the Kashmir Valley }\end{array}$ & $0.01-14$ \\
\hline 4 & Earth Tremors & TO BE INVESTIGATED \\
\hline 5 & Landslides & $0.05-5.0$ \\
\hline 6 & Rock Fractures & $0.02-5.0$ \\
\hline 7 & $\begin{array}{l}\text { Acoustics of the Kashmir Valley: The Valley can be vis } \\
\text { cavity (theoretical value of resonant frequency }<0.2 \mathrm{H} \\
\text { which could be sustained by mountain clear air turbule } \\
\text { around in the Valley) }\end{array}$ & $\begin{array}{l}\text { zualized as a U-Shaped resonant } \\
\text { z i.e. in the infrasound spectrum) } \\
\text { ence reverberating all the year }\end{array}$ \\
\hline
\end{tabular}

Geography \& Geology of the Kashmir Valley [5] is an intermontane valley lying in the western of Jammu and Kashmir State, in northern India. It is flanked by the main range of the Himalayas on the northeast and the Pir Panjal Range on the southwest. It is an ancient lake basin about $135 \mathrm{~km}$ long, $32 \mathrm{~km}$ wide and 1620 metres high that is drained by the upper Jhelum River. Lined by mountains that rise 3600 to 4800 metres, the Valley is sheltered from the wet southwest monsoon.

The 4 million population of the Kashmir region is concentrated in the Valley. 
The cumulative impact of tectono-geomorphic, geotechnical, socio-economic settings exacerbates the seismic hazard risk of the Valley to future earthquake events [4] (Figure 1).

Infrasound Risk Enhancement due to Geologic Factors: The geomorphology of the Valley is set out in Figure 2. Section line AB on Geological map depicts the inverse relationship between amplification and density of the material. The amplification is higher in the central sedimentary fill of the Valley.

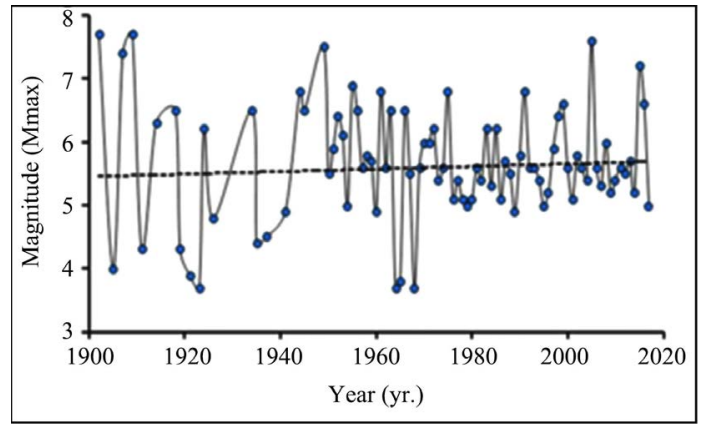

Figure 1. Earthquakes in Kashmir 2002-2017 [4].

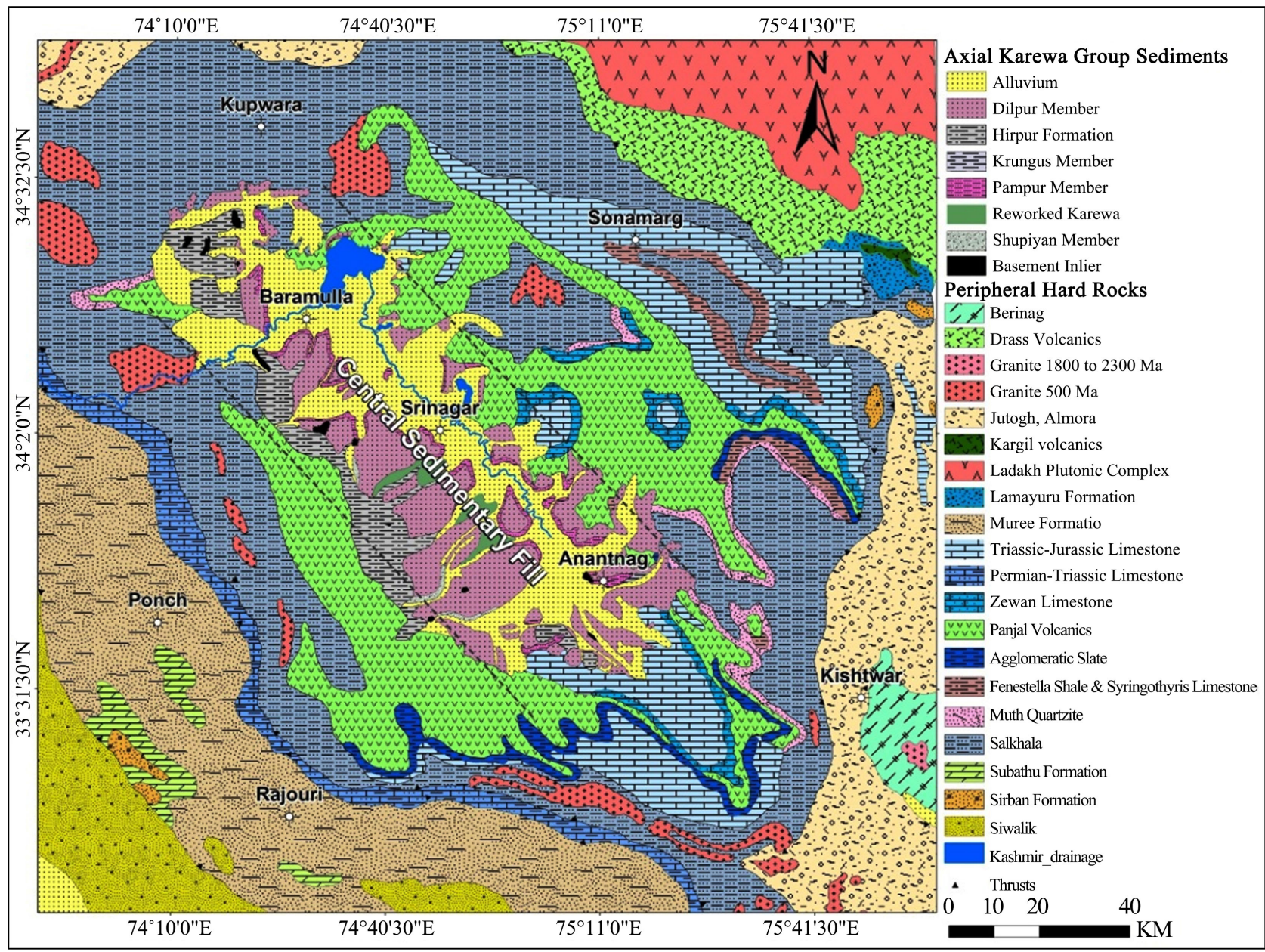

Figure 2. Geomorphology of Kashmir Valley showing tectonic lineament [4]. 
It is shown in Figure 2 how geologic conditions contribute significantly to the earthquake (hence, infrasound) hazard and risk enhancement. As a seismic wave traverses the Valley from the Pir Panjal range to the south to the Himalayan range to the north, the amplitude of ground oscillations (and hence that of infrasound) increases by almost a factor of 5 in the alluvial plains.

Infrasound Risk Enhancement by Acoustic Resonance due to Shape of the Valley: The Geological Cross-section of the Valley is shown in Figure 3. It can be seen that geologically, Kashmir is a U-shaped valley and hence for analysis may be treated as an acoustical cavity resonator.

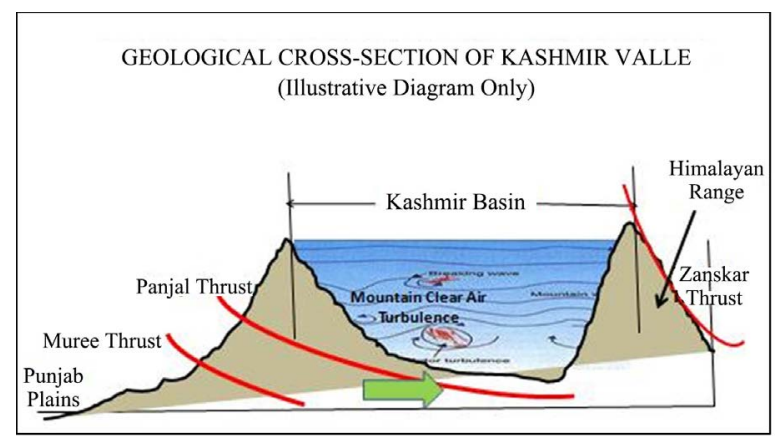

Figure 3. Infrasound resonance due to shape of the Kashmir Valley (Shape is Derived from Ref. 5).

The Kashmir Basin may be visualized as an acoustic cavity of size $l_{1}=$ height $=$ $3000 \mathrm{~m}, l_{2}=$ length $=135,000 \mathrm{~m}$ and $l_{3}=$ width $=32,000 \mathrm{~m}$. Detailed resonant frequency calculations bring out that this is between $0.02 \mathrm{~Hz}$ to $0.06 \mathrm{~Hz}$. Since infrasound frequencies range between 0.01 to $20 \mathrm{~Hz}$, it is clear that all sources of infrasound will resonate between 0.02 and $0.06 \mathrm{~Hz}$. It is known that infrasound from Mountain Clear Air turbulence has a frequency $0.01 \mathrm{~Hz}$ to $1.0 \mathrm{~Hz}$.

Hence it may be seen that Kashmir Valley because of its shape further enhances the infrasound hazard and probably sustains it on a $24 \times 7$ basis.

\section{Public Health Hazards Due to Infrasound}

Hearing Disabilities: The horrendous earthquake of M 7.6 (with infrasound amplitude $>180 \mathrm{~dB}$ at the epicentre) in 2005 wherein 80,000 people died could have insidiously left a significant proportion of Kashmiri population with hearing disabilities, post-traumatic stress disorders (PTSD), and low in energy. The Census of India in 2001 reports that while $5.6 \%$ of people in Kashmir then suffered from hearing disabilities; whereas the Census of 2011 found that hearing disabilities have escalated to affect $20.5 \%$ of the Kashmir population [6].

Psychological Disabilities: The Muntazar Kashmir Mental Health Report (2015) [7] report comprehensively brings out existence of widespread psychological ailments like depression, anxiety, annoyance and anger etc. as legitimate public reactions to the geopolitical situation, ascribing this strange condition specifically to the actions of security forces. This paper brings out there could be other legitimate reasons and perspectives for such chronic ailments in Kashmir 
Valley.

Correlations between infrasound spectra \& health hazards (Table 4) brings out a summary of direct correlations psychological problems due to infrasound emissions with psychological problems as brought out by the Muntazar Report. This table shows that a fundamental reason for the chronic mental health problems and issues in the Kashmir Valley could be exposure to environmental infrasound.

Table 4. Relationship between infrasound spectra and public health parameters as reported in Muntazar report.

\begin{tabular}{|c|c|c|c|c|}
\hline Sl. No & $\begin{array}{l}\text { Health Hazards Attributed } \\
\text { to Infrasound as Reported in } \\
\text { International Published } \\
\text { Studies (Appendix A) }\end{array}$ & Frequency & $\begin{array}{l}\text { Amplitude } \\
\text { (dB) }\end{array}$ & $\begin{array}{l}\text { Corresponding Kashmir Health Problems } \\
\text { Reported } \\
\text { Muntazar Kashmir Mental Health Report (2015) [7] }\end{array}$ \\
\hline 1 & PTSD & $1-10 \mathrm{~Hz}$ & $60-135 \mathrm{~dB}$ & $\begin{array}{l}\text { - High rates of co-morbidity of symptoms of depression, anxiety } \\
\text { and PTSD were found in adults living in the valley. }\end{array}$ \\
\hline 2 & $\begin{array}{l}\text { Heart Palpitation }+ \text { Blood } \\
\text { pressure decreased/decreased }\end{array}$ & 14 or $16 \mathrm{~Hz}$ & $14 \mathrm{~dB}-125 \mathrm{~dB}$ & $\begin{array}{l}\text { - Heart palpitations ( } 47 \%) \text {. } \\
\text { - Approximately } 1.6 \text { million adults }(41 \%) \text { in the valley are living }\end{array}$ \\
\hline 3 & $\begin{array}{l}\text { Severe depression, depression } \\
\text { anxiety related disorders }\end{array}$ & 0.50 to $10 \mathrm{~Hz}$ & $80 \mathrm{~dB}$ & $\begin{array}{l}\text { with significant symptoms of depression, with } 415,000(10 \%) \\
\text { meeting all the diagnostic criteria for severe depression. } \\
\text { - An estimated } 1 \text { million adults (26\%) in the valley are living with } \\
\text { significant symptoms of an anxiety related disorder. }\end{array}$ \\
\hline 4 & $\begin{array}{l}\text { Fear, sorrow, depression, } \\
\text { anxiety, nausea }\end{array}$ & 0.5 to $10 \mathrm{~Hz}$ & $>80 \mathrm{~dB}$ & $\begin{array}{l}\text { Nearly } 1 \text { in } 5 \text { adults (19\%) or } 771,000 \text { individuals in the Valley } \\
\text { are living with significant PTSD symptoms, with } 248,000 \text { (6\%) } \\
\text { meeting the diagnostic criteria for PTSD. }\end{array}$ \\
\hline 5 & Sleep disorders & $6-16 \mathrm{~Hz}$ & $80 \mathrm{~dB}-30 \mathrm{~dB}$ & $59 \%$ of population suffer difficulties in sleeping. \\
\hline 6 & Difficulty in concentration & $17 \mathrm{~Hz}$ & $14 \mathrm{~dB}$ & Having difficulty concentrating (52\%). \\
\hline 7 & Suicidal ideation & \multicolumn{2}{|c|}{ Spectral Data not Reported } & Suicidal ideation was reported by $12 \%$ of Kashmiri adults. \\
\hline 8 & Headaches & $7-20 \mathrm{~Hz}$ & & Regularly experiencing headaches (62\%). \\
\hline 9 & Low in energy & $5-10 \mathrm{~Hz}$ & $100-135 \mathrm{~dB}$ & $36 \%$ report being low in energy. \\
\hline 10 & $\begin{array}{l}\text { Annoyance and outbursts of } \\
\text { anger }\end{array}$ & All Frequencies & All Amplitudes & Feeling irritable and having outbursts of anger (65\%). \\
\hline 11 & Hearing disabilities & $20 \mathrm{~Hz}$ & $140 \mathrm{~dB}$ & $5.6 \%$ in 2001 Census, $20.9 \%$ in 2011 Census (Note: Great \\
\hline 11 & Hearing disabilities & $2 \mathrm{~Hz}$ & $162 \mathrm{~dB}$ & Muzzafarnagar Earthquake M 7.6, infrasound > 180 dB) in 2005. \\
\hline
\end{tabular}

\section{Exploratory Field Survey and Study}

Choice of Location: The study (Phase 1) was planned to verify assumptions of the earlier published work that infrasound hotspots are most likely to be found in locations on/around latitude $34^{\circ}$ north as indicated in Table 5. Ten more locations in northern and central Kashmir are also to be investigated (Phase 2).

\section{Infrasound Measuring Instruments}

At each site, the infrasound measuring instrument was co-located with a standard seismogram owned and operated by the Kashmir University which recorded earth movements in terms of acceleration vs. time; while the Infrasound instrument measured amplitude of infrasound vs. time. A typical field setup is illustrated in Figure 4. Components of the instrument are illustrated in Figure 5. 
Table 5. GPS coordinates of sites for recording infrasound.

\begin{tabular}{ccccc}
\hline Sl. No. & Location & Latitude & Longitude & Date of Recording \\
\hline 1 & Nagam & 33.927 & 74.786 & 15 Nov 18 \\
2 & KU & 34.128 & 74.836 & 15,16 \& 17 Nov 18 \\
3 & Awantipura & 33.927 & 75.02 & 17 Nov 18 \\
4 & Trapie & 34.016 & 74.523 & 19 Nov 18 \\
5 & Sitaharan & 33.925 & 74.58 & 19 Nov 18 \\
6 & Arigram & 33.918 & 74.087 & 20 Nov 18 \\
7 & Charar-i-Shariff & 33.853 & 74.754 & 23 Nov 18 \\
8 & Romshai & 33.85 & 74.837 & 23 Nov 18 \\
9 & Gulzarpora & 33.87 & 75.01 & 24 Nov 18 \\
10 & Batkoot & 33.93 & 75.29 & 25 Nov 18 \\
\hline
\end{tabular}

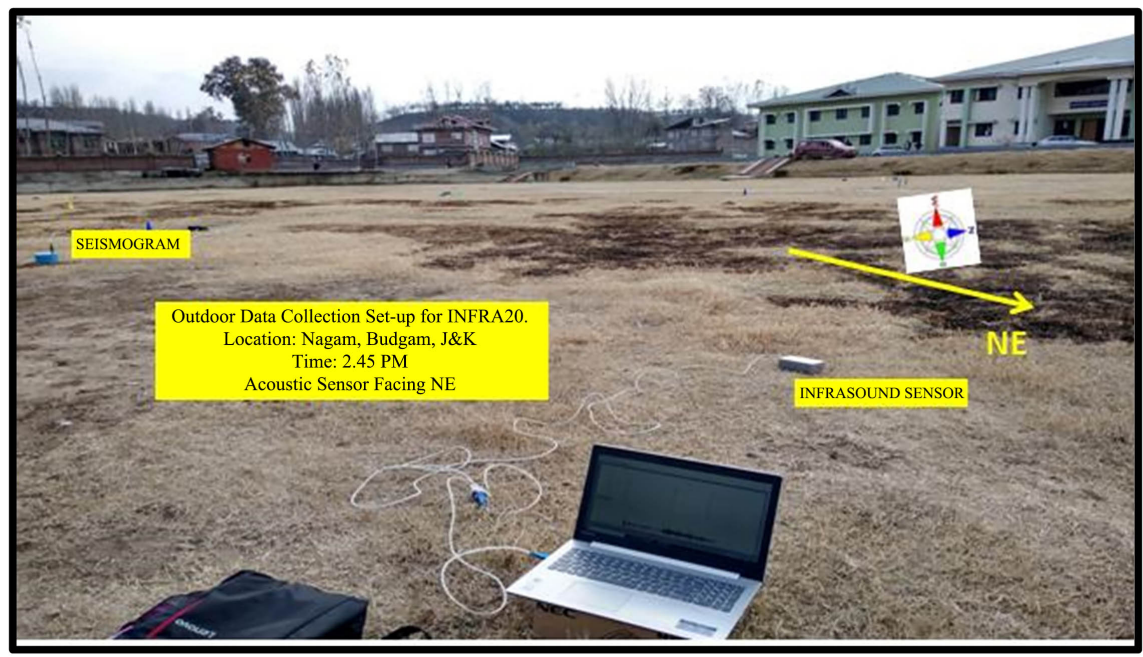

Figure 4. Instrumentation Set up in the Field.

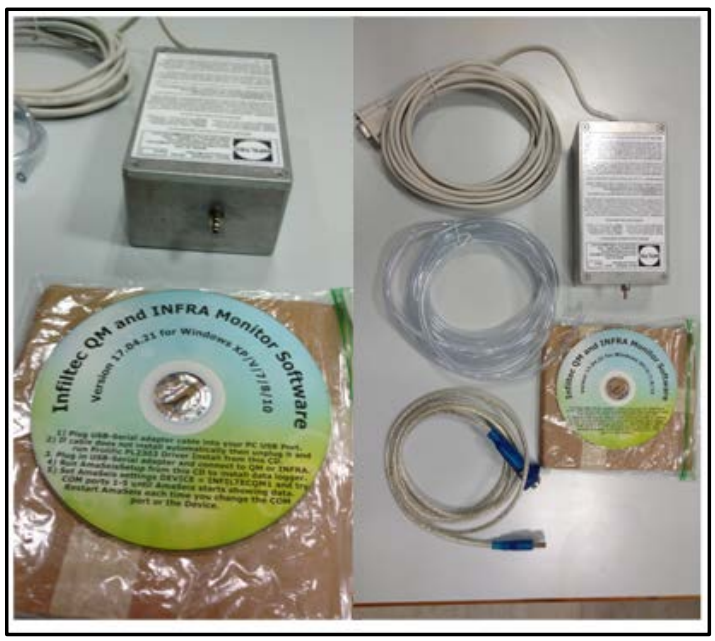

Figure 5. Components of INFRA 20 infrasound measuring instrument (WITH PERMISSION, Ms. Infiltec, USA). 


\section{Experimental Data and Analysis}

The transformation of the raw sensor output data in terms of magnitude (in counts, 100 counts is approximately $9.4 \mathrm{~dB}$ ) vs. time is stored on the hard disc and shown continuously on the PC screen in real time as long as the sensor is connected. Typical infrasound data located in Phase 1 at location \#7 is shown in Figure 6 and Figure 7. Wind noise model determined analytically is superimposed in Figure 6. No traffic noise was noted.

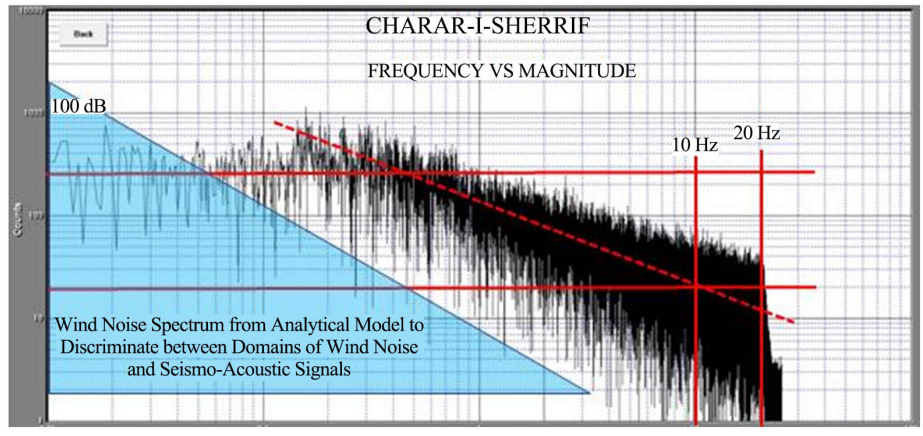

Figure 6. Typical recording of infrasound frequency $(\mathrm{Hz})$ vs. amplitude (dB).

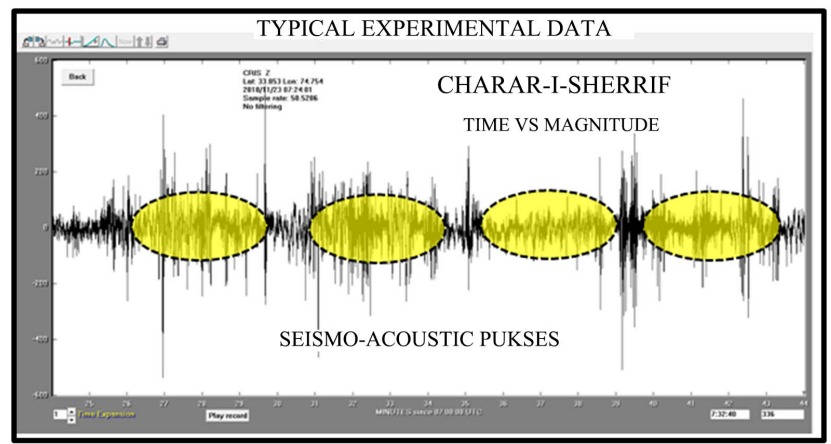

Figure 7. Typical recording: time vs. magnitude.

Summary of Field Study Measurements: The Time-amplitude and Frequency-Amplitude Infrasound Recordings at 10 locations described in Table 5 are placed in Appendix C. Key parameters extracted from Field Recordings are shown in Table 6. During this period there were no earthquakes of high magnitude. Hence these recordings serve as a baseline for times of minimum seismicity in Kashmir region.

Table 6. Summary of results of field studies from 15 Nov. 18 to 25 Nov 18 (Arranged in order of decreasing amplitude; frequencies at these amplitudes may be noted from Infrasound Spectra Charts at Appendix C).

\begin{tabular}{ccccccccc}
\hline Location & $\begin{array}{c}\text { Date (All Dates } \\
\text { in November } \\
\text { 2018) }\end{array}$ & Time & Latitude & Longitude & $\begin{array}{c}\text { Elevation } \\
\text { (Metres) }\end{array}$ & $\begin{array}{c}\text { Max. } \\
\text { Amplitude } \\
\text { (dB) }\end{array}$ & $\begin{array}{c}\text { W: Low } \\
\text { M: Medium } \\
\text { H: High } \\
\text { (Subjective) }\end{array}$ & $\begin{array}{c}\text { Infrasonic } \\
\text { (Number Per Minute) }\end{array}$ \\
\hline Trapie & 19 & O500 & 34.016 & 74.523 & 1867 & 40.00 & L & 2 \\
\hline
\end{tabular}




\begin{tabular}{|c|c|c|c|c|c|c|c|c|}
\hline Sataram & 19 & O900 & 33.925 & 74.58 & 2241 & 40.00 & $\mathrm{~L}$ & 2 \\
\hline Charar-i-Sheriff & 23 & O7.24 & 33.853 & 74.754 & 1933 & 30.00 & $\mathrm{H}$ & 5 \\
\hline Awantipura & 17 & $\mathrm{O} 435$ & 33.927 & 75.02 & 1582 & 20.00 & M & 3 \\
\hline Arigram & 20 & O820 & 33.918 & 74.087 & 1668 & 20.00 & M & 5 \\
\hline Gulzarpora & 24 & O8.38 & 33.87 & 75.01 & 1610 & 8.00 & M & 1 \\
\hline Nagam & 15 & 11.25 & 33.927 & 74.786 & 1610 & 6.00 & $\mathrm{~L}$ & 1.5 \\
\hline Batkoot & 25 & 11.10 & 33.93 & 75.29 & 1610 & 6.00 & M & $?$ \\
\hline Ramshai & 23 & $11.3 \mathrm{O}$ & 33.85 & 74.837 & 1610 & 5.00 & $\mathrm{H}$ & 2 \\
\hline $\begin{array}{l}\text { Kashmir } \\
\text { University }\end{array}$ & 15 & 1611 & 34.128 & 74.836 & 1592 & 2.50 & $\mathrm{H}$ & N/A \\
\hline $\begin{array}{l}\text { Kashmir } \\
\text { University }\end{array}$ & 16 & Not noted & 34.128 & 74.836 & 1592 & 2.50 & $\mathrm{H}$ & N/A \\
\hline $\begin{array}{l}\text { Kashmir } \\
\text { University }\end{array}$ & 17 & 1732 & 34.128 & 74.836 & 1592 & 2.50 & $\mathrm{H}$ & N/A \\
\hline
\end{tabular}

\section{Findings and Discussions on Field Studies Results}

The critical findings of this Field Study are

- The maximum amplitude locations lie within 0.02 degrees of 34 degrees north latitude thus validating the earlier (2017/2018) observations in published literature [3].

- They lie in very close proximity not only to Active Faults in the region of earthquake ruptures; and are also in proximity of a region of a large field of past earthquakes that took place in 2006-2012 extending to the Kishtwar region of Jammu.

- The infrasound frequency spectrum in all cases covers the entire infrasound region up to $20 \mathrm{~Hz}$. The infrasound emissions from earthquakes worldwide extend up to $14-16 \mathrm{~Hz}$. In this period of Study (November 2018) there were no major earthquakes in the region. Hence the source of these sustained emissions of infrasound is not from regional earthquakes. Subject to more research work, it is tentatively concluded that infrasound emissions are from boundaries of colliding tectonic plates nearby liberated from many Faults in the this part of the Kashmir region and mountain air turbulence at higher altitudes.

- Location Altitude vs. Infrasound Amplitude: The amplitude of infrasound appears to be related to altitude (i.e. elevation) of the location. It is seen from Figure 8 that higher amplitudes of infrasound are recorded at higher altitudes. This may be due to several reasons. Firstly, mountain air turbulence is likely to be higher at higher altitudes, thus increasing infrasound amplitude. Secondly infrasound "hotspot" activity in these regions may also be higher. 


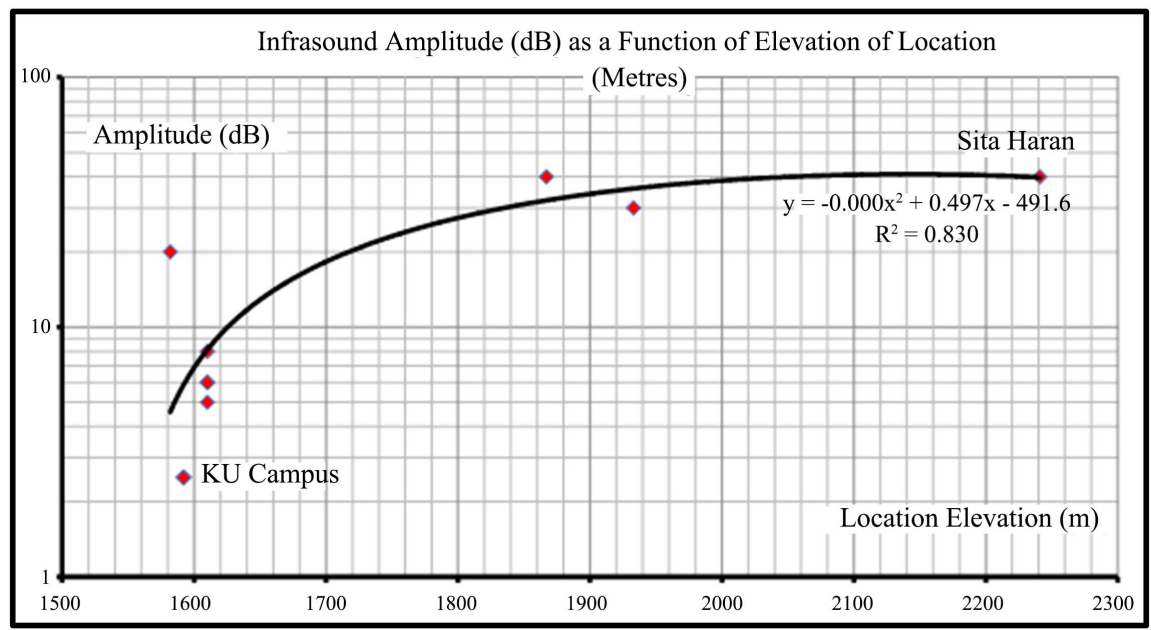

Figure 8. Regions of higher and lower infrasound located in Phase 1 (South Kashmir).

Infrasound was recorded for about 1 or 2 hours in each location. The extent of wind during the recording was subjectively assessed; while every precaution was used to protect the infrasound sensor being directly impacted by wind pressure. The recordings reported in Appendix $\mathrm{C}$ show a rhythmic infrasound wave pulses and the frequency of these "infrasound waves" was noted for analysis. No particularly distinct pattern was observed. Typical infrasound spectra in locations of maximum amplitude (Sita Haran, Trapie, and Charar-i-Sherrif) and minimum amplitude (in Kashmir University Campus) are shown in Figure 6, Figure 7 and Figure 9. Corrections as suggested by the manufacturer for altitude and

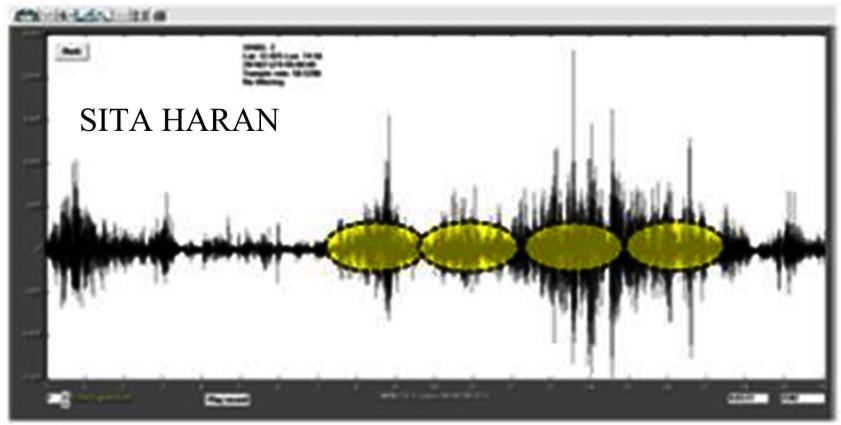

KU Campus 16 Nov 2018

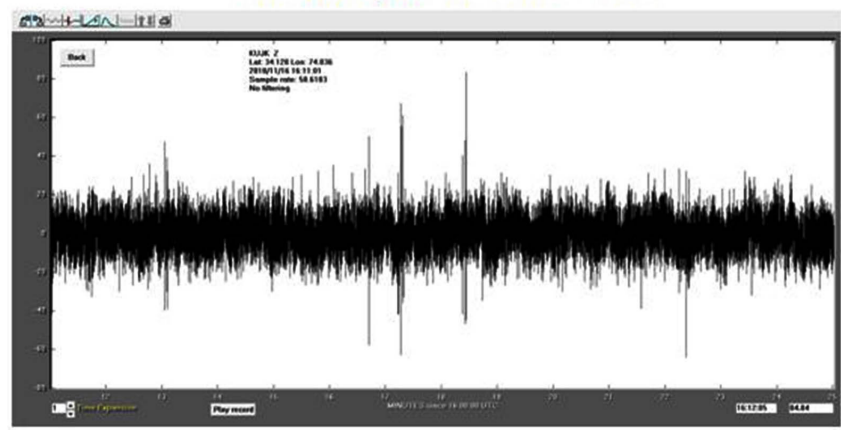

Figure 9. Infrasound pulses at different locations, reasons for different periodicity of pulses not known. 
ambient temperature were made. Earthquakes exhibit infrasound frequencies up to $14 \mathrm{~Hz}$. However in all locations the infrasound spectra extended to the full 20 $\mathrm{Hz}$ spectrum. These could best be ascribed to sustained energies released by colliding tectonic plates.

\section{Discovery of the Source of Infrasound Hot Spots in South Kashmir by Field Studies}

An attempt was made to discover the actual source of infrasound in the region surveyed for presence of infrasound. Four locations having highest amplitude are taken up for analysis as identified in Table 6 and Table 7

Table 7. Locations with maximum infrasound amplifications.

\begin{tabular}{|c|c|c|c|c|c|c|c|c|}
\hline Location & $\begin{array}{c}\text { Date (All Dates } \\
\text { in November } \\
\text { 2018) }\end{array}$ & Time & Latitude & Longitude & $\begin{array}{c}\text { Elevation } \\
\text { (Metres) }\end{array}$ & $\begin{array}{l}\text { Max. } \\
\text { Amplitude } \\
\text { (dB) }\end{array}$ & $\begin{array}{c}\text { Wind } \\
\text { L: Low } \\
\text { M: Medium } \\
\text { H: High } \\
\text { (Subjective) }\end{array}$ & $\begin{array}{c}\text { Infrasonic Wave } \\
\text { Periodicity } \\
\text { (Number per Minute) }\end{array}$ \\
\hline Trapie & 19 & O500 & 34.016 & 74.523 & 1867 & 40.00 & $\mathrm{~L}$ & 2 \\
\hline Sataram & 19 & O900 & 33.925 & 74.58 & 2241 & 40.00 & $\mathrm{~L}$ & 2 \\
\hline Charar-i-Sheriff & 23 & O7.24 & 33.853 & 74.754 & 1933 & 30.00 & $\mathrm{H}$ & 5 \\
\hline Awantipura & 17 & $\mathrm{O} 435$ & 33.927 & 75.02 & 1582 & 20.00 & M & 3 \\
\hline
\end{tabular}

These locations are now transferred to a map of Historical Geodesy [9] in the Kashmir Valley. This is shown in Figure 10.

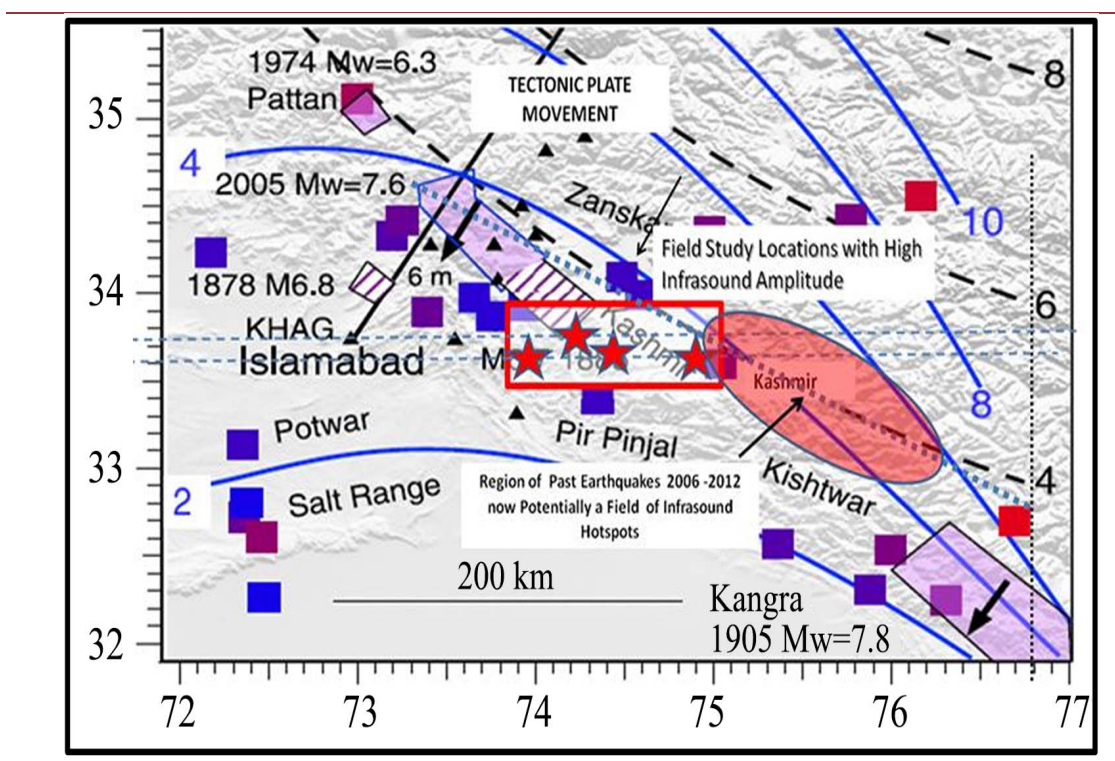

Figure 10. POTENTIAL LOCATION OF INFRASOUND HOTSPOT FIELD RESPONSIBLE FOR HIGH AMPLITUDE INFRASOUND EMISSIONS IN KASHMIR VALLEY.

Historical geodesy. Red ellipse indicates potential location for Infrasound Hot Spots within field of past earthquakes (2006-2012): from Figure 1 in [8]. 
Small black triangles indicate trigonometric points linking the nineteenth century Great Trigonometrically Survey of India to the Russian Survey network measured in 1913 (Mason 1914). Colour-coded squares indicate GPS velocities relative to India obtained in the past 30 years. Smoothed blue solid contours indicate southwards velocity; dashed black contours indicate westwards velocity. Earthquake ruptures are indicated by violet shading with the magnitudes indicated. Hatched areas indicate pre-instrumental earthquakes in the late nineteenth century.

Source: Roger Bilham. Figure 1 "Himalayan earthquakes: a review of historical seismicity and early 21st century slip potential" CIRES and Geological Sciences, University of Colorado Boulder, 216 UCB, Boulder, CO 80309, USA, 0000-0002-5547-4102. From: TRELOAR, P. J. \& SEARLE, M. P. (eds) Himalayan Tectonics: A Modern Synthesis. Geological Society, London, Special Publications, 483.

This is an Open Access article distributed under the terms of the Creative Commons Attribution 3.0 License

(http://creativecommons.org/licenses/by/3.0/). Published by The Geological Society of London. Publishing disclaimer: www.geolsoc.org.uk/pub_ethics.

Figure 10. Identification of the locations of real sources of infrasound in Kashmir Region.

The Sources of Infrasound in the Kashmir Valley: The multiple sources of environmental infrasound in Kashmir have been brought out in Table 3. There were no earthquakes or landslides in this period. Hence the likely sources of infrasound were from tectonic plate movements, teleseismic activity from global seismic events and due to local/regional seismic activity; mountain air turbulence and earth tremors.

\section{The Breakthrough Discovery of Infrasound Hotspots from This Field Study}

It can be seen that actual locations of the high amplitude infrasound as located in this Field Study are:

1) Lying in very close proximity along the centerline of Active Faults in the region of earthquake ruptures.

2) The earthquake rupture region is also in proximity of a region of a large field of past earthquakes that took place in 2006-2012 (this data obtained from another published source [8]).

3) Along the foot hills of Pie Punjab range rocks are highly deformed to accommodate the stresses due to upliftment of Pir Punjab range along Punjab thrust; and continuous convergence of Indian plate against Asian plate. Kashmir Valley is an Intermountain Nappe zone basin which is under continuous deformation.

\section{Location-Wise Amalgamation of Infrasound Emissions with Public Health Hazards}

Using the Infrasound Systems Integration Table set out in Table 1, a technique has been developed to amalgamate the Field Study recordings with Public Health Hazards at that specific location and that specific year, month, and date. This methodology is indicated in Figure 11. Table 8 shows the Legend to use to describe the public health hazard in Sita Haran as a typical example. 


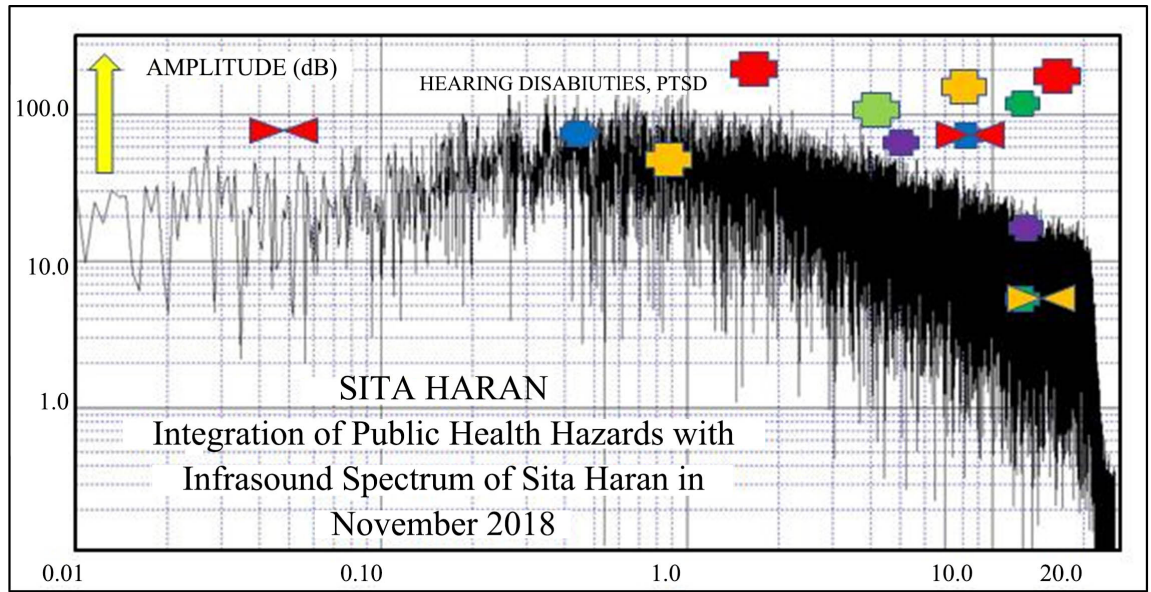

Figure 11. Public health hazards in Sita Haran in November 2018 as related to infrasound spectrum of this location.

Table 8. Legend relating public health hazard to infrasound.

\begin{tabular}{|c|c|c|c|c|}
\hline Sl. No. & $\begin{array}{l}\text { Health } \\
\text { Hazards }\end{array}$ & $\begin{array}{l}\text { Frequency } \\
(\mathrm{Hz})\end{array}$ & $\begin{array}{l}\text { Amplitude } \\
\text { (dB) }\end{array}$ & Symbol \\
\hline 1 & Hearing Disabilities & $2-10$ & $140-162$ & \\
\hline 2 & PTSD & $1-10$ & $60-135$ & \\
\hline 3 & Low in Energy & $5-10$ & $\begin{array}{l}10-135 \\
>15 \text { minutes }\end{array}$ & \\
\hline 4 & $\begin{array}{l}\text { Heart Palpitation + Blood } \\
\text { pressure increased/decreased }\end{array}$ & 14 or 16 & $14-125$ & \\
\hline $5,6,7$ & $\begin{array}{l}\text { Severe depression, depression, } \\
\text { anxiety related disorders }\end{array}$ & $0.5-10$ & 80 & \\
\hline 8 & Sleep disorders & $6-16$ & $80-30$ & \\
\hline 9 & $\begin{array}{l}\text { Fear, sorrow, depression, } \\
\text { anxiety, nausea }\end{array}$ & $0.5-10$ & $>80$ & \\
\hline 10 & Difficulty in concentration & 17 & 14 & \\
\hline 11 & Suicidal Ideation & Data not reported & --- & --- \\
\hline 12 & Headaches & $7-20$ & --- & --- \\
\hline 13 & $\begin{array}{l}\text { Constant annoyance and } \\
\text { outbursts of anger }\end{array}$ & All Frequencies & All Amplitudes & \\
\hline
\end{tabular}

Infrasonic Health Hazards in a Specific Location (Sita Haran): From these two figures it is seen that people in Sita Haran in Budgam District. Probably 10\% - $20 \%$ of the population would be suffering historically from the following ailments due to sustained exposure to infrasound:

1) Severe depression, depression and anxiety related disorders;

2) PTSD;

3) Heart palpitation and blood pressure disorders and;

4) Difficulty in concentration. 
Comparison of Health Hazards Reported in Muntazar Report with Findings of this Study: The Muntazar Kashmir Mental Health Report 2015 also reports a similar finding for mental distress averaged in the whole district of Badgam. Page 86, Figure 1 of this Report indicates that a male/female average of $40 \%$ suffer identical ailments of mental distress as could also be caused by infrasound.

It may however be noted that this difference between $22 \%$ due to infrasound on that particular date in November 2018 in a specific single location in Badgam district and on another date earlier in 2015 by comprehensive medical investigations in the whole district are quantitatively different. This is explained because the accumulated public health data is due to sustained infrasound over decades through a variety of high seismic activity over the entire District of Badgam; whereas in the period of this environmental infrasound in a specific location in Badgam district, the valley was relatively seismically quiet with no earthquakes during the field study period. The content of distress in medical terms is however identical between the Muntazar Kashmir Mental Health Report (2015) and this Study on Public Health Hazards due to Environmental Infrasound.

\section{Comments on Muntazar Kashmir Mental Health Report 2015}

The Muntazar 2015 Kashmir Mental Health Report covers medical investigations and studies carried out over just one year. This time-span is completely inadequate to comment on the source and causal relationships of public health hazards in Kashmir. Hence long term (1937 to 2018) longitudinal time-series analysis of infrasound amplitude from earthquakes of M 6 and greater in Kashmir has been carried and results are shown in Figure 12, which is based on the history of earthquakes in Kashmir (placed at Appendix B).

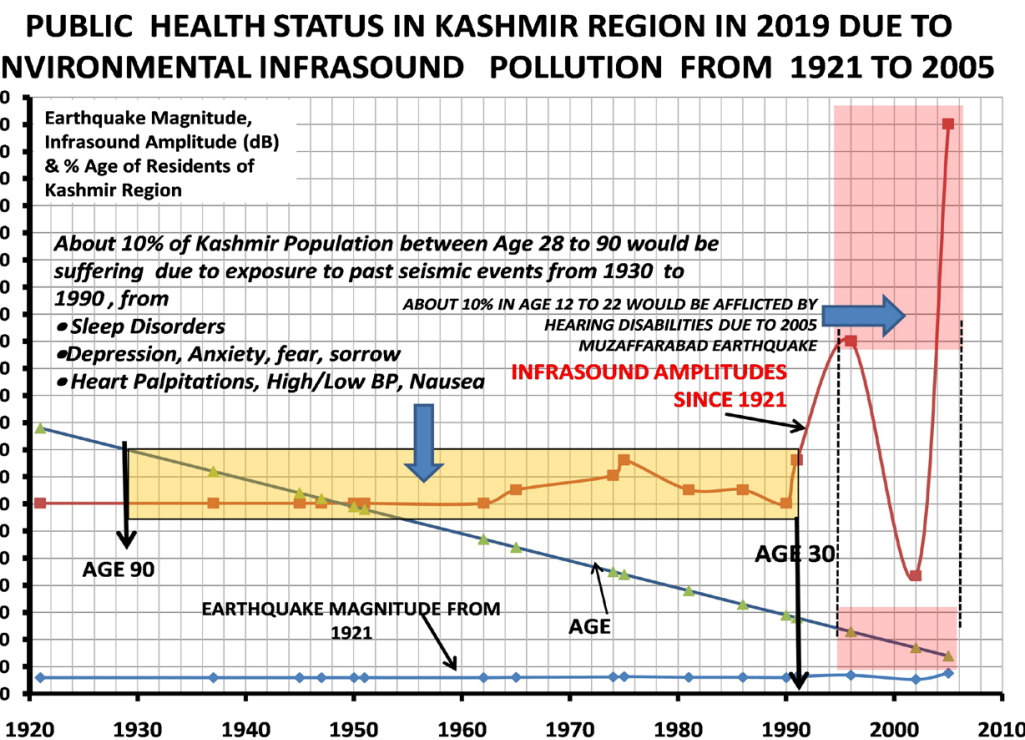

Figure 12. Time series analysis (1937-2018) for public health hazards in Kashmir Valley due to local earthquakes in the period (Derived from data at Appendix B). 
This finding i.e. historicity of health ailments due to infrasound contradicts the Muntazar Report that indicates that such distress which as that Report describes, "has reached epidemic proportions" is of recent origin. This is not so. The psychological ailments like $10 \%-22 \%$ of population being in a sustained state of annoyance and anger due to infrasound may surely have been aggravated by the fight against the oppression and suffering caused cross-border violence in some locations like Srinagar the summer capital of the region, but the latter was surely not the fundamental cause in many other locations as brought out by this alternate perspective based on blending the many themes of modern science.

Other Limitations of the Muntazar Kashmir Mental Health Report: The Muntazar survey focuses only on psychological ailments and does not include physiological investigations like for widespread hearing disabilities. It has been shown in this Study that high intensity earthquakes like the M 7.6 earthquake of 2005 were also the cause of hearing disabilities. The presence of such high levels of hearing diseases surely cannot be caused by geopolitical factors as the Muntazar Report suggests.

Infrasound Cancellation/Mitigation Technologies: It is reported that Passive Noise Cancellation Technologies can be as simple as providing acoustic fences around the infrasound hotspot once located. Active noise control (ANC), also known as noise cancellation, or active noise reduction (ANR), is a method for reducing unwanted sound by the addition of a second sound specifically designed to cancel the first. Such active (powered by solar energy) and passive infrasound cancellation materials metamaterials (e.g. honeycomb epoxy substrate embedded with powdered refractory materials) and related technologies can be developed; while research on infrasound absorbance of photonic crystals needs to be emphasized.

Better and rapidly growing understanding of geo-acoustics of environmental infrasound pollution and deployment of these technologies could well usher joy instead of sorrow in affected regions and be the precursor to a new era of world peace. For those who see the invisible can make the impossible possible.

\section{Recommendations}

Following recommendations are made for action to address the effects and causes of hazardous environmental infrasound in Kashmir Valley:

1) Mobilise all possible government as well as community resources to provide comprehensive medical facilities for the age-old public health situation in Kashmir now aggravated by the exponential increase in population, now about 4 million. Educate the population to this hazard and measures being taken so that enhanced self-awareness mitigates social violence.

2) Phase 2 of this Infrasound Exploration Study (in Northern regions) needs to be completed urgently. Additional budgetary support is needed to complete this preliminary study. 
3) Very detailed infrasound studies are taken up by Central Government with more sophisticated instrumentation to precisely locate all these infrasound hotspots not only in South Kashmir but in the entire Kashmir Valley.

4) Thereafter an extensive and intensive Infrasound Cancellation/Mitigation Programme may be taken up by Government with the Private Sector.

5) A permanent field of networked infrasound observatories is set up in the Kashmir Valley.

6) In the longer term (within six months to one year) there is need to;

a) To develop and strengthen comprehensive policies for promotion of a robust Public Health Security System to standards that equal those in California USA like mental health as well as;

b) To develop and commission location-wise evidence-based infrasound cancellation systems and/or infrasound barriers as done world-over in windmill farms;

c) Urgently develop integrated centre-state and collaborative international seismo-acoustic research UN programs for better understanding of sources of environmental infrasound and public health hazards in Kashmir and other regions in the world.

Note on Responsibilities of Co-Authors: The Principal Investigator is responsible for the analysis and views expressed in development of the theory of environmental infrasound; its linkage to public health hazards; and the interpretation of the field recordings in regard to these aspects. The three other co-authors as duly authorized were responsible only for the primary goal of this Field Study: to plan, conduct field operations, to detect, discover and record environmental infrasound in Kashmir Valley.

\section{Acknowledgements}

The authors acknowledge with respect and gratitude the inspiration and sustained moral support of the former Governor of Jammu \& Kashmir, Mr. Narinder Nath Vohra IAS (Retd) without whom this study would ever have been initiated. We are thankful to Sri. Y. Satyanarayana and Ms Srilakshmi of CIM Technologies, Hyderabad who checked out the infrasound instrument when it was received and verified its functioning. We thank Mr. David Saum, CTO, and Mr. Frankie of MsInfiltec USA who was ever available on emails to help diagnose and trouble shooting in the process of recording infrasound and its spectral analysis.

\section{Conflicts of Interest}

The authors declare no conflicts of interest regarding the publication of this paper.

\section{References}

[1] Jammu \& Kashmir Tourism Development Department. https://www.jktdc.co.in/History-of-Kashmir.html 
[2] Gopalaswami, R. (2017) Environmental Infrasound Pollution and Its Effects on Human Populations. Journal of Environment Pollution and Human Health, 5, 93-98. http://pubs.sciepub.com/jephh/5/3/3/index.html

[3] Gopalaswami, R. (2018) A Study on the Correlation of Physiological and Psychological Health Hazards in Human Habitats with Seismicity, Mountain Air Turbulence and Environmental Infrasound. Open Journal of Earthquake Research, 7, 69-87. http://www.scirp.org/journal/OJER https://doi.org/10.4236/ojer.2018.72005/

[4] Chandra, R., et al. (2018) Seismic Hazard and Probability Assessment of Kashmir Valley, Northwest Himalaya, India. CSIR Fourth Paradigm Institute, Bangalore.

[5] Ahmed, S. (1975) Tectonic Evolution of Kashmir Valley. Geological Cross-Section of Kashmir Valley.

https://www.researchgate.net/figure/274572826_fig2_Fig-2-Geological-cross-sectio n-of-the-Kashmir-Himalayas-after-Wadia-1975

[6] Naik, A.A. and Selvarajan, E. (2015) Disabled Population: A Temporal Study of Jammu and Kashmir. Journal of Business Management \& Social Sciences Research, $4,16$.

[7] Kashmir, M. (2015) Mental Health Report. Muntazar: Kashmir Mental Health Survey Report 2015, Médecins Sans Frontières (MSF), the University of Kashmir, Institute of Mental Health and Neurosciences (IMHANS), MSF, New Delhi.

[8] Sharma, S., Kumar, A. and Ghangas, V. (2013) Seismicity of Jammu \& Kashmir Region with Special Reference to Kishtwar. International Journal of Scientific Research and Publications, Figure 1, 3, 1-5.

[9] Bilham, R. (2019) Himalayan Earthquakes: A Review of Historical Seismicity and Early 21st Century Slip Potential. Geological Society, London, Special Publications, 483. 


\section{Appendix A}

\section{HEALTH HAZARDS DUE TO EXPOSURE TO INFRASOUND}

\section{As Updated on 17 Mar 19}

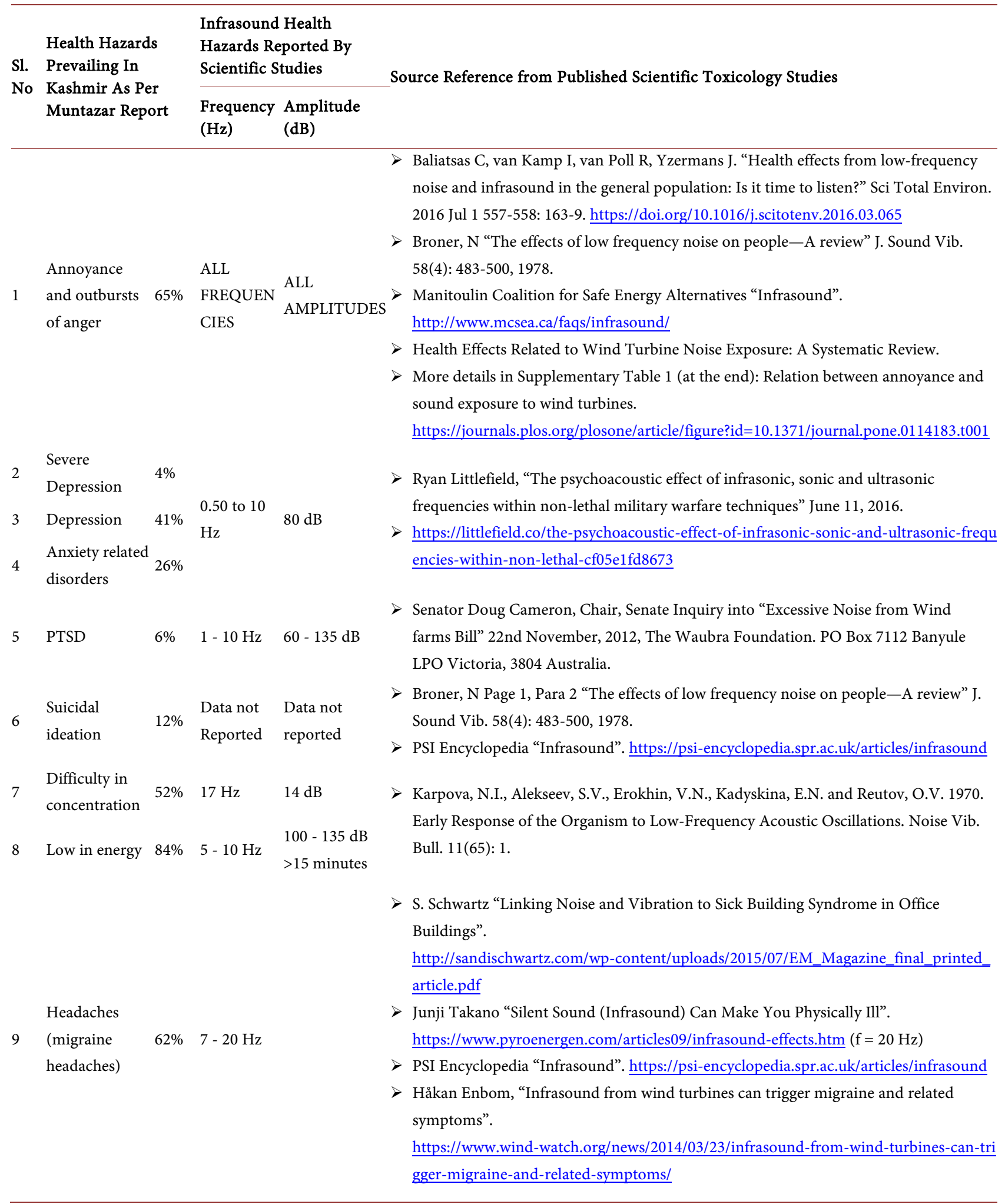




\section{Continued}

Dawson H, "Practical Aspects of Low Frequency Noise Problem" Rolls Royce Ltd, Journal of Low Frequency Noise \& Vibration, Vol 1, No. 1, January 1982. https://docs.wind-watch.org/Dawson-LFN-Problem.pdf

Fear, sorrow,

11 depression, anxiety, nausea
$14 \mathrm{~Hz}$

$16 \mathrm{~Hz}$

Blood

10

$\begin{array}{lll}\text { Heart } & 47 \% & \text { pressure } 14 \mathrm{~dB} \\ \text { palpitation } & & \text { decreased/ } 125 \mathrm{~dB} \\ & \text { decreased } \\ & 14 \text { or } 16 \mathrm{~Hz}\end{array}$
$\begin{array}{lll}\text { Hearing } & 20 \mathrm{~Hz} & 140 \mathrm{~dB} \\ \text { disabilities } & 2 \mathrm{~Hz} & 162 \mathrm{~dB}\end{array}$

0.5 to $10 \mathrm{~Hz}>80 \mathrm{~dB}$
Sleep disorders
INFRASOUND October 1, 2010.

https://www.eastcoastrip.org/weather-and-the-paranormal/2017/1/22/infrasound

> Naik AA and Selvarajan E "Disabled Population: A Temporal Study of Jammu and Kashmir" Journal of Business Management \& Social Sciences Research (JBM\&SSR) Volume 4, No. 11, November 2015; ISSN No: 2319-5614 (1981 to 2001: 5.6\% of population 2001 to 2011: 20.5\% of population.

$>$ Broner, N Para 3.4 "The effects of low frequency noise on people-A review" J. Sound Vib. 58(4): 483-500, 1978.

$>$ Lindström, I.M., et al. (1997) The Effects of Ultrasound on Humans. Rep., Umea

> University, Umeå, 33, 1-42.

Exposures to 6 and $16 \mathrm{~Hz}$ at levels $10 \mathrm{~dB}$ above the auditory threshold have been associated with a reduction in wakefulness (Ref. 28 National Toxicology Program). Jan 13, 1999.

Auditory level: $16 \mathrm{~Hz}: 30 \mathrm{~dB}$ and at $6 \mathrm{~Hz}: 80 \mathrm{~dB}$.

\section{Appendix B}

\section{Earthquake History from Several References}

Ref.1 Earthquake History of Kashmir, Jannat e Kashmir, Nadeem Bashir Khan, https://mykashmirvalley.wordpress.com/earthquake-history-of-kashmir/.

Ref.2 Earthquakes in Jammu \& Kashmir, India http://asc-india.org/seismi/seis-jnk.htm.

\begin{tabular}{|c|c|c|c|c|}
\hline Sl. No & Date & $\begin{array}{l}\text { Magnitude of } \\
\text { Earthquake }\end{array}$ & Location & $\begin{array}{c}\text { Reference } \\
\text { Sl. No }\end{array}$ \\
\hline 1 & 06 May 1828 & 6.0 & $\begin{array}{c}\text { Srinagar area (Jammu \& Kashmir), } \\
\quad 34.08 \mathrm{~N}, 74.833 \mathrm{E}\end{array}$ & 2 \\
\hline 2 & 30 May 1885 & 7.0 & $\begin{array}{l}\text { NW of Srinagar } \\
34.60 \mathrm{~N}, 74.38 \mathrm{E}\end{array}$ & 1 \\
\hline 3 & 17 May 1917 & 6.0 & $\begin{array}{l}\text { Ladakh } \\
34.20 \mathrm{~N}, 77.50 \mathrm{E}\end{array}$ & 1.2 \\
\hline 4 & 11 Nov 1921 & 6.0 & $\begin{array}{l}\text { Ladakh } \\
34.20 \mathrm{~N}, 77.50 \mathrm{E}\end{array}$ & 1.2 \\
\hline 5 & 15 Nov 1937 & 6.0 & $\begin{array}{l}\text { Northern Ladakh } \\
35.10 \mathrm{~N}, 78.10 \mathrm{E}\end{array}$ & 1.2 \\
\hline
\end{tabular}




\section{Continued}

6

7

10 July 1947

12 Aug 1950

12 Aug 1950

12 Sep 1951

11

12

22 Jun 1965

13

28 Dec 1974

14

28 Apr 1975

12 Sep 1981

06 Jul 1986

06 Jul 1986

05 Mar 1990

25 Mar 1990

19 Nov 1996

28 Jan 2002

01 Nov 2002

03 Nov 2002

08 Oct 2005

23 Oct 2005

2012

2012

2012

2012
6.0

6.0

6.0

6.0

6.0

6.0

6.1

4

3.2

5.2
Near Padua, Kathwa District, J\&K (H.P.-J\&K Border region)

$32.599 \mathrm{~N}, 75.90 \mathrm{E}$

Near Padua,

Kathwad District, 32.599N, 75.90E

Near Padua,

Kathwad District,

$32.599 \mathrm{~N}, 75.90 \mathrm{E}$

Gilgit Wazarat (P.O.K.)

$36.20 \mathrm{~N}, 73.00 \mathrm{E}$

Chamba-Udhampur Districts (H.P.-J\&K Border region), $33.30 \mathrm{~N}, 76.50 \mathrm{E}$

Udhampur District $33.30 \mathrm{~N}, 76.20 \mathrm{E}$

Ladakh $36.30 \mathrm{~N}, 77.70 \mathrm{E}$

NE of Malakhand, NWFP, (Indo-Pakistan Border region), 35.054N, 72.870E

Aksai Chin (Indo-China Border region), $35.819 \mathrm{~N}, 79.915 \mathrm{E}$

Gilgit Wazarat (P.O.K.) $35.693 \mathrm{~N}, 73.594 \mathrm{E}$,

\section{Xizang}

(Indo-China Border region) $34.424 \mathrm{~N}, 80.161 \mathrm{E}$

$$
\text { Xizang }
$$

(Indo-China Border Region),

$34.424 \mathrm{~N}, 80.161 \mathrm{E}$

Gilgit Wazarat (P.O.K.)

$36.907 \mathrm{~N}, 73.021 \mathrm{E}$

Gilgit Wazarat (P.O.K.), $37.034 \mathrm{~N}, 72.942 \mathrm{E}$

Aksai Chin (Indo-China Border region), $35.345 \mathrm{~N}, 78.133 \mathrm{E}$,

Kithar, $33.100 \mathrm{~N}, 75.987 \mathrm{E}$

Astore Valley, P.O.K., $35.361 \mathrm{~N}, 74.718 \mathrm{E}$

Astore Valley, P.O.K., $35.359 \mathrm{~N}, 74.636 \mathrm{E}$,

Kashmir-Kohistan, Pakistan-India border, 34.432N, 73.537E

Kashmir-Kohistan aftershock, $34.884 \mathrm{~N}, 73.024 \mathrm{E}$,

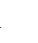
http://www.imd.gov.in/pages/earthquake_prelim.php

(1)

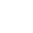

(1)

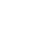




\section{Continued}

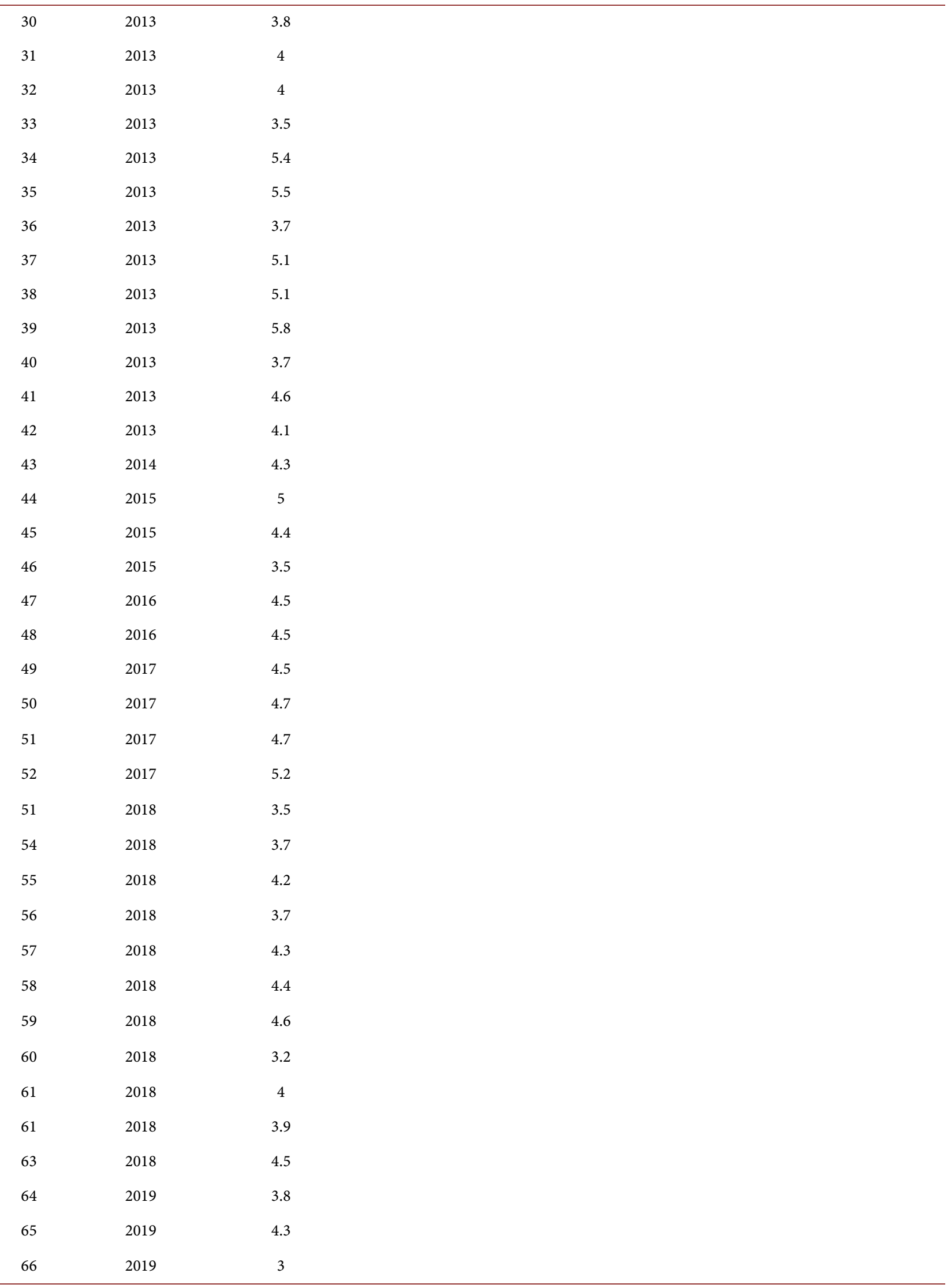




\section{Appendix C}

ENVIRONMENTAL INFRASOUND IN KASHMIR VALLEY

FIELD STUDY RESULTS

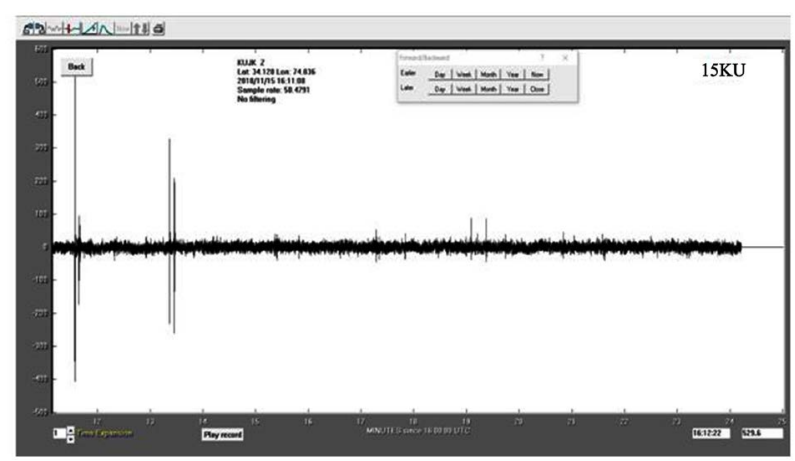

KU Campus 15 Nov 2018
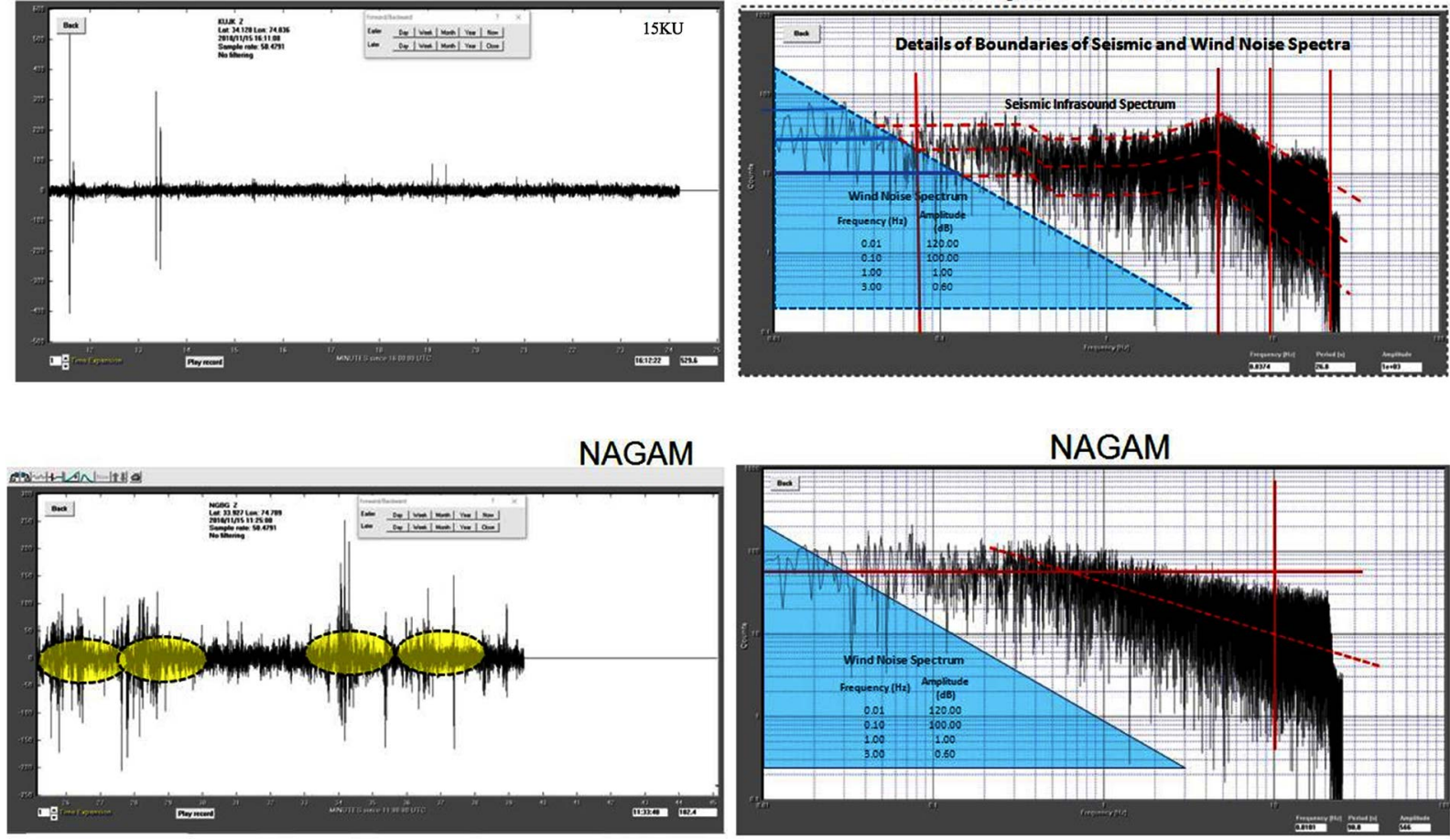

KU Campus 16 Nov 2018

KU Campus 16 Nov 2018
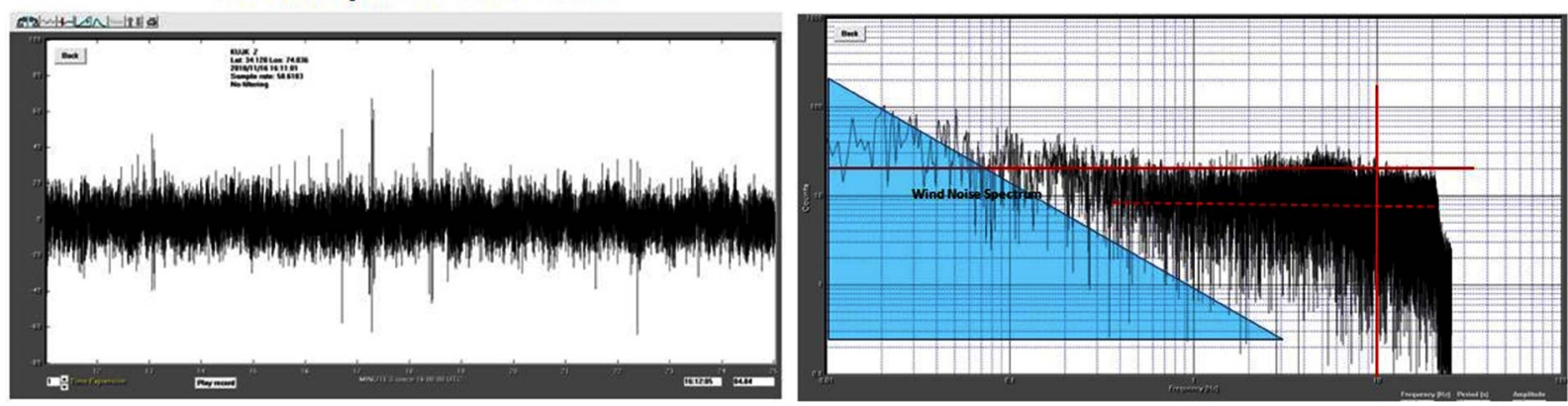

KU Campus 17 Nov 2018

KU Campus 17 Nov 2018
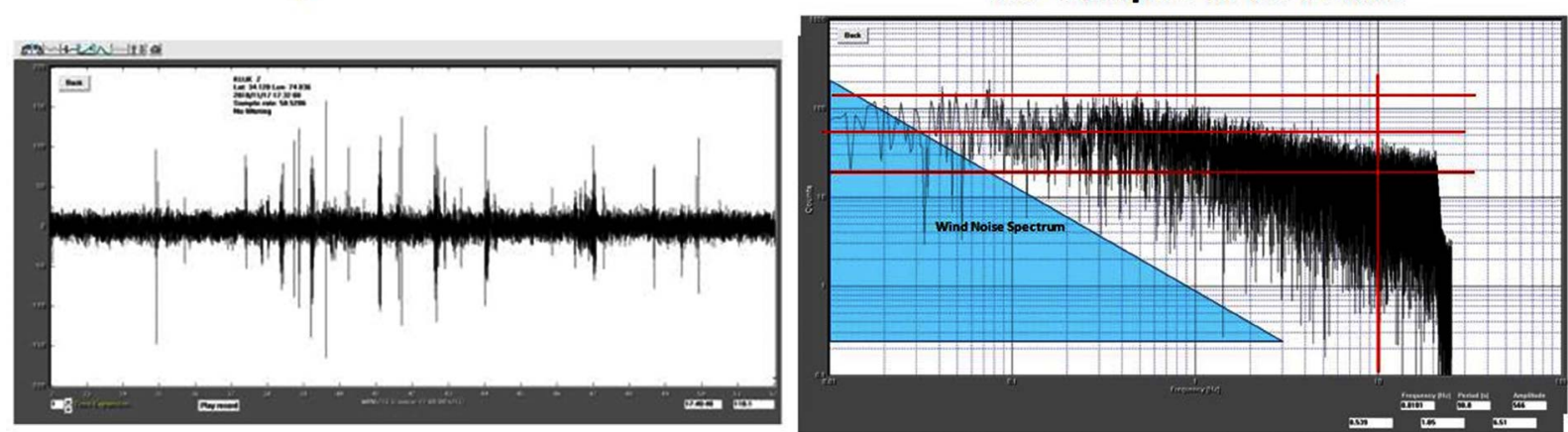

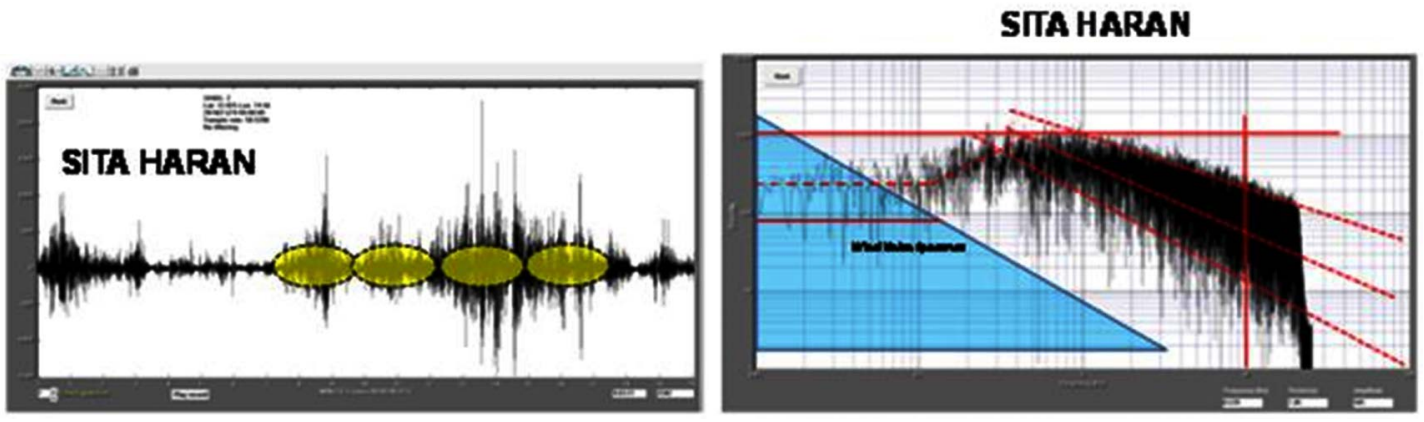

TRAPIE

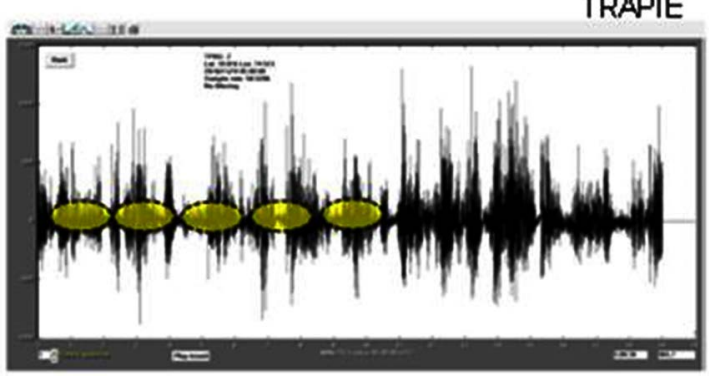

TRAPIE
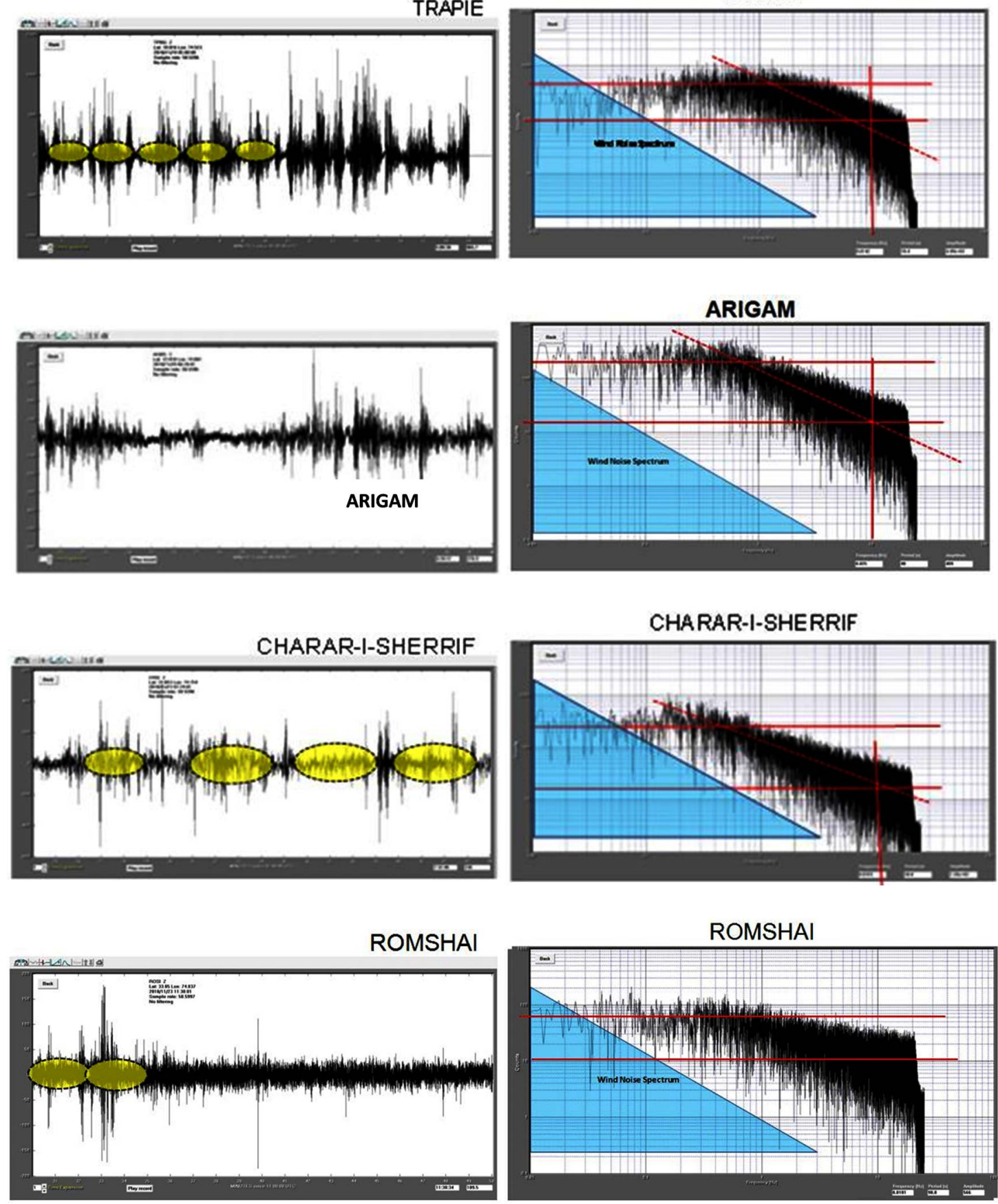

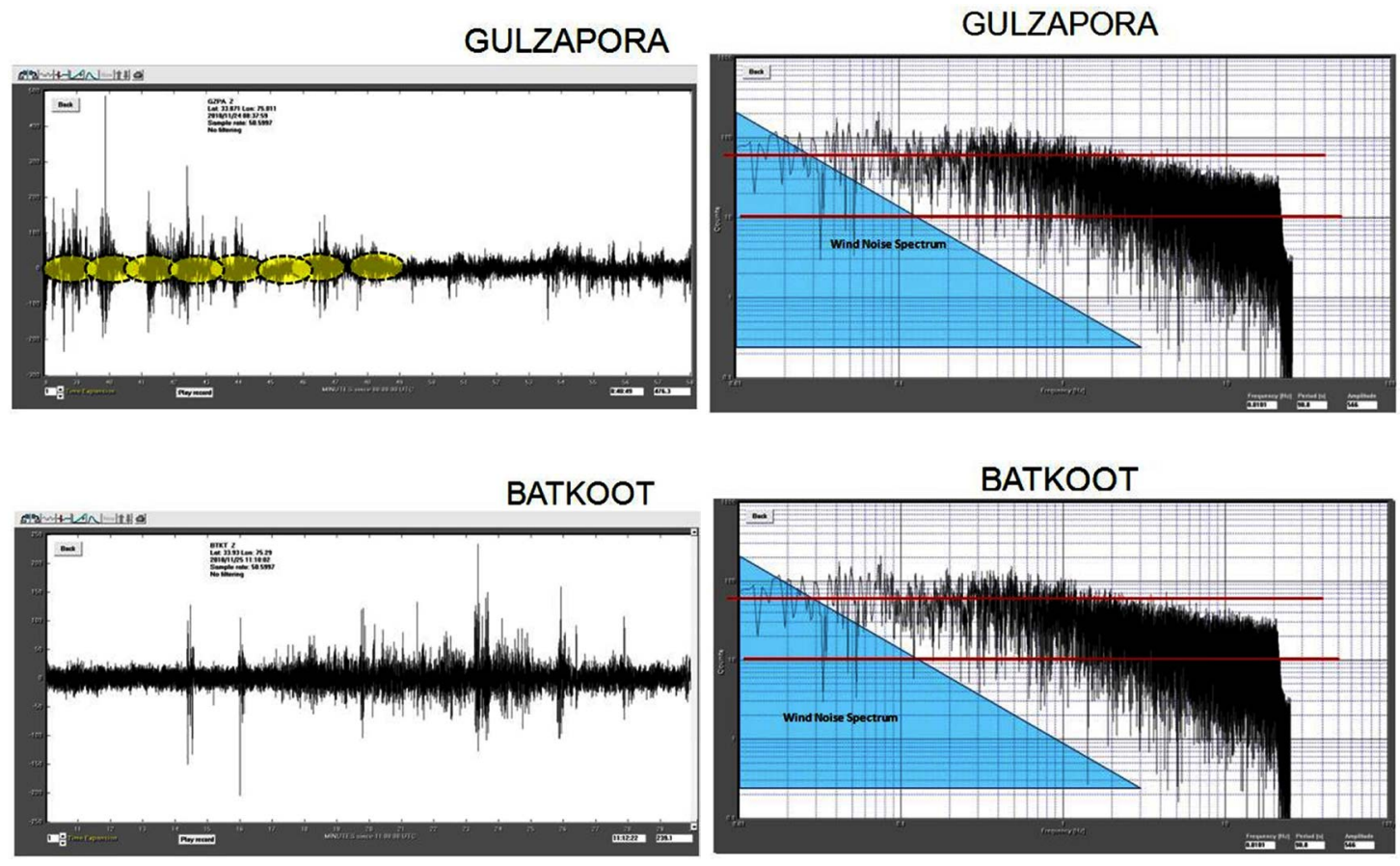